\author{
ALICJA PIHAN-KIJASOWA, AGNIESZKA MOTYL \\ Uniwersytet im. Adama Mickiewicza w Poznaniu
}

\title{
GŁÓWNE PROBLEMY NORMALIZACJI POLSZCZYZNY XVII WIEKU
}

Pierwsze uwagi i oceny siedemnastowiecznej polszczyzny pojawiły się już na początku XX wieku i były to uwagi zdecydowanie negatywne. W takim duchu o języku tego okresu wypowiadał się Aleksander Brückner, dostrzegając w nim przede wszystkim nadmierne wpływy łacińskie. Brücknerowska opinia, mówiąca o „obumarciu języka”, utrwalona na kilka dziesięcioleci w nauce ${ }^{1}$, znacznie wyprzedziła właściwe badania historycznojęzykowe nad XVII stuleciem. Przed połową XX wieku nie powstały bowiem żadne znaczące analizy siedemnastowiecznej polszczyzny. Nic więc dziwnego, że nie tylko Tadeusz Lehr-Spławiński, Stanisław Słoński, ale nawet jeszcze Zenon Klemensiewicz w swojej Historii języka polskiego sąd taki powtarza, twierdząc, że od lat czterdziestych XVII wieku poziom języka „obniża się na tle ogólnego cofania się życia polskiego pod znakiem sarmatyzmu” (Klemensiewicz 1974: 216). Negatywna opinia ulega weryfikacji, gdy w drugiej połowie XX wieku zaczynają się ukazywać szczegółowe studia nad polszczyzną XVII wieku. Już Maria Kamińska w 1953 roku przedstawiła wyniki swoich analiz nad grafią druków, pokazując rządzące nią zasady (Kamińska 1953)². Lata następne przyniosły kilka przyczynków i szkiców z zakresu różnych problemów szczegółowych (np. Siekierska 1962; Rykiel 1963; Siekierska 1969; Rzepka 1968), a także monograficzne opracowania języka niektórych siedemnastowiecznych autorów (Borek 1967; Puzynina 1961) ${ }^{3}$. Badania znacznie zostały zaawansowane od lat siedemdziesiątych $\mathrm{XX}$ wieku. W dalszym ciągu dominowały, co prawda, drobne szkice, artykuły i przyczynki szczegółowe (np. Breza 1979; Kosyl 1978; Kowalska 1973; Rzepka 1978; 986), ale ukazywały się też znaczące, ważne dla poznania polszczyzny XVII wieku opracowania monograficzne (np. Jefimow 1970; Pawłowska 1979; Pihan-Kijasowa 1999, Rzepka 1975; 1985; Siekierska 1974; Wróbel 1987) oraz księ-

\footnotetext{
1 Szczegółowy przegląd stanowisk i ich interpretacja patrz: Motyl 2009.

2 Niewiele wcześniej, bo w 1947 roku, ukazał się przeglądowy artykuł Zdzisława Stiebera (Stieber 1947).

3 A także cykl obszernych studiów o języku Samuela Twardowskiego autorstwa Iwona Szlesińskiego publikowanych w „Rozprawach Komisji Językowej Łódzkiego Towarzystwa Naukowego” w kilku kolejnych tomach, poczynając od roku1968 (Szlesiński 1968; Szlesiński 1970a; Szlesiński 1970b; Szlesiński 1971).
} 
gi zbiorowe poświęcone temu okresowi (Wiśniewska, Kosyl 1984; 19924; Stępień, Urbańczyk 19925). Jednak dopiero w 2002 roku wydana została syntetyczna monografia Polszczyzna XVII wieku. Stan i przeobrażenia. Praca zbiorowa pod red. D. Ostaszewskiej (Ostaszewska 2002) $)^{6}$.

Książka katowickich autorów, prezentująca cały system gramatyczny oraz ortografię i fonetykę siedemnastowiecznej polszczyzny, nie zamyka jednak badań nad tym okresem. Stwierdziłybyśmy nawet, że pobudza do dalszych analiz, odkrywając wiele nowych pól badawczych. Autorzy, chcąc w niewielkiej książce przedstawić wszystkie językowe problemy, nawet okresowe „osobliwości”, większość z nich, siłą rzeczy, zaprezentowali w sposób ogólny, świadomie rezygnując w pewnych istotnych zagadnień, jak np. regionalne zróżnicowanie tempa przebiegu procesów językowych. Choć w monografii wspomina się o procesach normalizacyjnych, jednak, zapewne z uwagi na ogólne ujęcie, zabrakło precyzyjnego zestawienia uzyskanych wyników z aprobowanymi w nauce historycznojęzykowej tzw. progami normalizacji, wyznaczonymi niegdyś przez Irenę Bajerową (Bajerowa 1980: 111) i dopracowanymi później przez Wojciecha Ryszarda Rzepkę (Rzepka 1985: 18). Warto więc, zwłaszcza temu ostatniemu problemowi, a więc normalizacji siedemnastowiecznej polszczyzny, poświęcić nieco uwagi.

Definicją i rozumieniem pojęcia norma wielokrotnie już się zajmowano, przedstawiając różne na ten temat koncepcje (por. np. Buttler, Kurkowska, Satkiewicz 1971; Borecki 1974; Bajerowa 1980; Książek-Bryłowa 1986; Skubalanka 1992; Lisowski 1999, Migdał 1999). Zebrał je, usystematyzował i twórczo rozwiną Tomasz Lisowski w pracy Polszczyzna XVI wieku. Problemy wariantywności i normalizacji fonetyki i fleksji (Lisowski 1999). Nie ma więc potrzeby przywoływania w tym miejscu omówionych już problemów. Przypomnę jedynie, że w zależności od czasu historycznego, jaki rozważamy, będziemy mówić o różnych poziomach normy, przede wszystkim o normie skodyfikowanej (teoretycznej) (Bajerowa 1980: 110) i normie tekstu (inaczej normie praktycznej (Bajerowa 1980: 110) bądź uzusie (Bajerowa 1986: 9).

Badacze nowszych dziejów polszczyzny, a więc doby nowopolskiej, dysponują odpowiednimi podstawami źródłowymi, by móc ukazywać wzajemny stosunek normy skodyfikowanej, wyłożonej w różnego typu wydawnictwach teoretycznych (podręczniki gramatyki języka polskiego, wydawnictwa poprawnościowe itp.), i normy tekstu. W odniesieniu do okresów wcześniejszych, jeszcze nawet wieku XVIII, możemy jedynie, na podstawie szczegółowych analiz materiałowych, odtworzyć normę tekstu, a przez zestawienie tekstów rozłożonych w czasie - wskazać przebieg i poziom procesu normalizacyjnego. Takie też właśnie są nasze możliwości, jeśli chodzi o interesujący nas wiek XVII. Problem pojawia się natomiast, gdy dla tego czasu chcemy odtworzyć normę teoretyczną, skodyfikowaną, i pokazać jej ewentualną ewolucję. Jak konstatuje Wojciech Ryszard Rzepka, badacz siedemnastowiecznej fleksji, „Przyczyny [tego problemu] są przynajmniej dwie. Źródeł

4 Książka będąca pokłosiem konferencji naukowej poświęconej polszczyźnie XVII wieku.

5 Tom przynoszący kilka istotnych studiów językoznawczych.

6 Autorami poszczególnych rozdziałów monografii są: Urszula Burzywoda, Danuta Ostaszewska, Artur Rejter, Mirosława Siuciak.

7 Por. np. „Wśród odnotowanych osobliwości przeważają formy z osobliwym - $a, \mathrm{z}$ których najczęstsze to: klasztora [...]" (Ostaszewska 2002: 76). 
precyzujących NT [normę teoretyczną] jest stosunkowo niewiele (ich ciąg chronologiczny otwiera gramatyka Statoriusa-Stojeńskiego z 1568 r.), a ponadto nie wszystkie z nich - jak ustalił P. Zwoliński - są wiarygodne. [...] W tej sytuacji trudno określać postępy w zakresie NT na podstawie stosunku ilościowego wypowiedzi aprobujących i negatywnych" (Rzepka 1985: 19). I trudno się z autorem tej opinii nie zgodzić. Wypada ją jednak uzupełnić o kilka informacji szczegółowych. Wspomniany Przemysław Zwoliński, weryfikując bibliografię gramatyk polskich autorstwa Barbary Otwinowskiej, Lucylli Pszczołowskiej i Jadwigi Puzyniny, dla XVII wieku przyjmuje, że wydano ich 48. Nie wszystkie jednak, choć znalazły się w wykazie, gramatykami nazwać możemy. Są wśród nich ortografie, rozmówki polsko-obcojęzyczne, wzory listów, słowniki. 14 zaś do dziś znanych jest tylko z tytułów, trudno więc domniemywać o ich zawartości. Wobec tego na miano rzeczywistych gramatyk zasługuje - jak twierdzi P. Zwoliński - tylko 12 pozycji (Zwoliński 1988: 33). Ale pamiętać też należy, że niektóre $z$ tych dzieł były wydawane więcej niż jeden raz. Ich więc dostępność była spora, i choć z założenia przeznaczone były dla cudzoziemców uczących się języka polskiego, to ich oddziaływania, choćby pośredniego, na stosunek mówiących do języka, na poziom świadomości językowej nie można negować, zwłaszcza że niektóre, jak gramatyka Macieja Gutthaetera-Dobrackiego (Olesch 1992: 131-139) czy Jana Karola Woyny, cechowały się wyraźną postawą normalizacyjną. Zwłaszcza w gramatyce Woyny dostrzegamy wyraziste elementy świadomej normatywności. Autor zwięźle, a czasem wręcz apodyktycznie formułuje reguły językowe. Normalizująca świadomość Woyny rozciąga się także na leksykę. Do swego dziełka dołączył słownik liczący ponad 600 wyrazów, które określa jako „obsoleta, barbara et inusitata”, czyli wyrazy przestarzałe i gwarowe (Zwoliński 1988: 59). M. Dobracki natomiast w swojej gramatyce formułuje kilka zasad zwłaszcza ortograficznych (Olesch 1992: 135).

Sądzimy, że do tego trzeba, bez obawy popełnienia błędu, dodać także podręczniki łacińskie - przeznaczone, tym razem, dla uczących się w szkołach Polaków. Jak informuje Halina Wiśniewska, autorka szkicu o sytuacji języka polskiego w XVII wieku: „Bardzo liczną grupę stanowią podręczniki łacińskie, ale z obszerną egzemplifikacją polską. [...] Podręczniki te unaoczniają, że język ojczysty stanowił w szkole przedmiot nauczania. [...] w podręczniku J. Ursinusa, profesora zamojskiego [...] polskich haseł mamy 3 tysiące, ponadto zawiera on traktaty o polskiej ortografii, wzorce odmian rzeczowników, zaimków, stopniowania przymiotników, podziały na grupy semantyczne" (Wiśniewska 1992: 11). Prac takich w XVII wieku wydawano sporo. Jak informuje H. Wiśniewska: „Kwerenda polskich archiwów pozwoliła odnaleźć 96 rękopiśmiennych retoryk z różnych kolegiów [...] i stwierdzić, że około 30 zawiera przykłady polskie, [...] wzory mów okolicznościowych, cytaty z wierszy J[ana] Kochanowskiego, M[ikołaja] Sarbiewskiego i S[amuela] Twardowskiego" (Wiśniewska 1992: 12). Tak więc z całą pewnością i one dla uczących się stanowiły wzorzec poprawności językowej.

Oczywiste jest, że wspomniane wyżej źródła, choć bardzo istotne w badaniach nad świadomością językową, nad ówczesnym rozumieniem tego, co poprawne, a więc zalecane, i tego, co nie zyskiwało aprobaty autorów, nie daje jednak dostatecznych podstaw do rekonstrukcji XVII-wiecznej normy teoretycznej. O takiej bowiem, w odniesieniu do omawianego okresu i w świetle dzisiejszej wiedzy, raczej mówić nie można. Możemy jedynie uchwycić , ,...] te momenty, w których formy ekspansywne w orzeczeniach gramatykarzy i zestawianych przez nich paradygmatach wysuwają się na plan pierwszy, co może świad- 
czyć o ich akceptacji i stabilizowaniu się jako obowiązującej normy" (Rzepka 1985: 19). Pozostajemy więc przy wstępnym założeniu, że dla XVII wieku w sposób pełny i// uargumentowany możemy mówić jedynie o normie tekstu. Dla XVII stulecia źródeł do badania tego problemu, a więc normy tekstu, jest wystarczająco dużo. Jak ustalił Władysław Korotaj, w ciągu XVII wieku ukazało się ponad 5000 druków (chodzi oczywiście o liczbę tytułów, a nie wydrukowanych egzemplarzy) (Korotaj 1970: 290) ${ }^{8}$. Zachowało się też wiele tekstów rękopiśmiennych, reprezentujących różne odmiany stylistyczne. Podstawy badawcze są więc wystarczające.

Przebieg procesu normalizacji, rozłożony w czasie, najprecyzyjniej można przedstawić w sposób statystyczny. Ujęcie dynamiczne uzyskamy poprzez wyznaczenie w badanym wycinku czasowym kilku przekrojów synchronicznych, określenie poziomu normalizacji w każdym z nich, a następnie przez ich zestawienie ukażemy postępy w przebiegu procesu normalizacyjnego9 . Ponieważ normalizacja odbywa się poprzez wybór jednego z konkurujących wariantów, wariantu progresywnego (Książek-Bryłowa 1992: 173 i n.), a usunięcie lub przynajmniej ograniczenie używania wariantu regresywnego (Książek-Bryłowa 1992: 173 i n.), przyjmuje się zazwyczaj, jak wcześniej wspominałyśmy, zaproponowane przez badaczy jeszcze w latach osiemdziesiątych $\mathrm{XX}$ wieku ${ }^{10}$ tzw. progi normalizacyjne: do 50\% - brak normy, od 51\% do 74\% - wstępna normalizacja, od 75\% do 94\% - niepełna normalizacja, powyżej 95\% - pełna normalizacja.

Tak rzecz ujmując, na podstawie różnych dotychczasowych opracowań już wstępnie można przyjąć, że wiek XVII po wieku XVI odziedziczył język w wysokim stopniu znormalizowany na różnych poziomach: ortograficznym, fonetycznym i morfologicznym. I choć w wielu problemach szczegółowych albo odziedziczył, albo wytworzył współfunkcyjne warianty, generalnie niewiele było faktów, które nie prezentowałyby przynajmniej stanu niepełnej normalizacji, czyli nie osiągnęły choćby poziomu 75\%. Przy czym, jak podkreśla Marek Cybulski, „Mówiąc o normie siedemnastowiecznej polszczyzny, należy precyzować, o jakiej konkretnie normie mówimy, była ona bowiem co najmniej dwuwarstwowa: w drukach realizowana była norma «wyższa», bardziej rygorystyczna, w rękopisach natomiast «niższa», liberalniejsza, zapewne regionalnie zróżnicowana" (Cybulski 1992: 25). Używając terminologii Marka Cybulskiego, uściślamy, że nas interesuje norma wyższa, norma realizowana w ówczesnych drukach.

Mając na uwadze ograniczone ramy artykułu, materiał ilustrujący problem normalizacji siedemnastowiecznej polszczyzny ograniczamy do nielicznych, arbitralnie dobranych przykładów.

Z zakresu ortografii warto odwołać się do problemu pisowni fonetycznej, ujawniającej różne procesy asymilacyjne i redukcje grup spółgłoskowych w wyrazach. Jest to najbardziej, zapewne, dostrzegana przez badaczy cecha ówczesnych druków. Jednocześnie była niegdyś jednym z argumentów negatywnej oceny języka tego okresu. Skłonność do pisowni fonetycznej wsparta była autorytetem Grzegorza Knapskiego, który w trzecim tomie

\footnotetext{
8 Podobne liczby przytaczają: Urbańczyk 1992: 241; Topolska 1984: 133 i Rzepka 1975: 17.

9 Taki sposób postępowania zaproponowała i w praktyce badawczej zastosowała Irena Bajerowa (Bajerowa 1964; Bajerowa 1986; Bajerowa 1992).

10 Procentowe ujęcie procesu normalizacji zaproponowała Irena Bajerowa (Bajerowa 1980: 111), doprecyzował Wojciech Ryszard Rzepka (Rzepka 1985: 18).
} 
Thesaurusa, objaśniając podstawy stosowanej przez siebie ortografii, tak pisał: „Ja idę w ślady tych, którzy uważają, że należy tak pisać, jak się wymawia" ${ }^{11}$. Zjawisko pisowni fonetycznej odnotowuje wielu badaczy polszczyzny XVII wieku (Ostaszewska 2002: 37-38; Pihan-Kijasowa 1999: 51-52), jednak bez podawania frekwencji i ekstensji tekstowej, określając je jednak jako „, Jedną z właściwości XVII-wiecznej grafii” (Ostaszewska 2002: 37), która powoduje, ,[...] że w przejrzanych drukach mamy do czynienia z dużą wariantywnością ortografii nawet w obrębie tego samego tekstu” (Pihan-Kijasowa 1999: 51).

Szczegółowe badania Anny Pyrkosz (Pyrkosz 2010) obraz ten doprecyzowały, ale też znacznie zmodyfikowały. Badaczka wykazała, że w pierwszym 150-leciu polskiego drukarstwa pisownia fonetyczna grup spółgłoskowych sprowadza się głównie do ujawniania ubezdźwięcznień śródwyrazowych i międzywyrazowych, sporadycznie tylko występowały zapisy z grupami udźwięcznionymi. Przy czym dla drugiej połowy XVI wieku, a więc okresu bezpośrednio poprzedzającego interesujący nas wiek XVII, fonetyczna pisownia grup spółgłoskowych stanowi mniej niż 2\% wszystkich zapisów grup w analizowanych próbach tekstów. Wiek XVII nie tylko nie podwyższył liczby zapisów zasymilowanych, ale nawet znacznie je zmniejszył - zaledwie do 0,3\%. Oczywiście w poszczególnych tekstach odsetek takich zapisów był różny. Największą skłonność do pisowni fonetycznej wykazywała oficyna Franciszka Cezarego, mniejszą - Bazylego Skalskiego, Szymona Kempiniego czy Waleriana Piątkowskiego (Pyrkosz 2010: 233-235). Generalnie autorka stwierdza, że w badanym wycinku czasowym, „[...] asymilacja spółgłosek z pewnością nie należy do zjawisk masowych czy powszechnych, jednak w każdym okresie badawczym pojawiają się zapisy, w których doszło do upodobnień w obrębie grupy spółgłoskowej. Na podstawie badanego materiału [...] zaobserwować można spadkową tendencję w zakresie liczby zapisów ujawniających wewnątrzwyrazowe asymilacje pod względem dźwięczności. Najwięcej poświadczeń odnotowano $\mathrm{w}$ pierwszym okresie badawczym, nieco mniej w drugim, w trzecim natomiast już tylko $0,3 \%$. [...] stopniowa eliminacja zasymilowanych zapisów spowodowana jest - jak konstatuje autorka - postępującą petryfikacją uzusu ortograficznego, eliminującą cechy typowe dla polszczyzny mówionej” (Pyrkosz 2010: 238). Jak dalej pokazuje badaczka, w zakresie ubezdźwięcznień międzywyrazowych tendencja jest odwrotna: ,[...] najmniej poświadczeń jest w najstarszym okresie badawczym, ich liczba wzrasta natomiast w kolejnych”. Jednak „Ubezdźwięcznienia międzywyrazowe mają raczej charakter indywidualny - nie występują bowiem we wszystkich tekstach. Stosowanie tego typu rozwiązań ortograficznych zależne było od uzusu panującego w konkretnej oficynie wydawniczej" (Pyrkosz 2010: 239). A więc asymilacje międzywyrazowe, choć wykazywały tendencję wzrostową, i tak stanowiły zaledwie margines w ówczesnym zwyczaju ortograficznym.

Okazuje się więc, że nie tylko w XVI, ale też w XVII wieku, dla którego podkreślaną przez badaczy tendencją była pisownia fonetyczna, wsparta, jak to już powiedziano, autorytetem Grzegorza Knapskiego, normą tekstu była jednak pisownia etymologiczna grup spółgłoskowych. Wariantywne zapisy fonetyczne, tak rzucające się w oczy, były, jak pokazują szczegółowe badania Anny Pyrkosz, rzadkie i nigdy nie naruszyły progu pełnej normalizacji (95\%) w odniesieniu do zapisów etymologicznych, czyli nigdy nie przekroczyły, a nawet nie zbliżyły się do 5\% użyć.

11 Cyt. za: Puzynina 1961: 95 (przekład z języka łacińskiego Jadwigi Puzyniny). 
Jednym z najważniejszych problemów fonetyki, nie tylko XVII wieku, ale całej doby średniopolskiej, jest sprawa tzw. samogłosek pochylonych, kontynuujących zarówno staropolskie samogłoski długie, jak i nowych - pozycyjnych, powstałych wskutek sąsiedztwa fonetycznego. Zagadnienie to było wielokrotnie rozważane i opisywane przez badaczy historycznej polszczyzny. Podsumowaniem wiele lat trwającej dyskusji jest praca Ireny Bajerowej O zaniku samogłosek pochylonych (pokłosie dyskusji) wydana w 1978 roku w Katowicach. Natomiast pozycji samogłosek pochylonych w polszczyźnie XVII wieku, a także pisownianemu uzusowi $\mathrm{w}$ zakresie ich odróżniania w ówczesnych drukach, ze szczegółowym rozpisaniem na kategorie gramatyczne, pozycje fonetyczne i rdzenie wyrazowe poświęcone jest studium Zakresy występowania $a-\dot{a} w$ drukach pótnocnokresowych XVII wieku (Pihan-Kijasowa 1994b) oraz, szczegółowiej, jeden z rozdziałów monografii Literacka polszczyzna kresów pótnocno-wschodnich. Fonetyka (Pihan-Kijasowa 1999: 69-83). I choć podstawowy materiał badawczy obu prac pochodzi z druków wydanych w regionalnych oficynach północnokresowych, to jednak został on przedstawiony i zinterpretowany w konfrontacji z materiałem pochodzącym z druków wielkopolskich, małopolskich i mazowieckich, co daje podstawę do wnioskowania o stanie pochylonej samogłoski å w literackiej polszczyźnie ogólnej XVII wieku. Szczegółowe badania prowadzą do konstatacji, że XVII wiek był bardzo ważnym, jeśli nie decydującym, okresem w rozwoju tej samogłoski. Polski system fonetyczny odziedziczył po XVI wieku dobrze osadzoną w systemie pochyloną głoskę å. W grafii zazwyczaj odpowiadała jej litera $a$, podczas gdy niższa artykulacyjnie, jasna głoska $a$ zapisywana była literą á. We wszystkich poddanych oglądowi pozycjach i kategoriach, we wszystkich regionach, odsetek nieprawidłowych zapisów głoski pochylonej waha się od 0 do kilku procent. Można więc mówić o pełnej normalizacji w zakresie użycia å (i odpowiadającej jej w grafii litery $a$ ) w początkach XVII wieku ${ }^{12}$. Ówczesne źródło normatywne, jakim był bez wątpienia Thesaurus Grzegorza Knapskiego, zgodnie z tradycją rozróżniało $\mathrm{w}$ grafii obie te głoski, stosując odpowiednio litery $a$ i á, nie tylko w pierwszym, ale też w drugim wydaniu słownika (Puzynina 1961: 99). Kolejne dziesięciolecia początkowy stan pełnej normalizacji znacznie naruszają. Jednak przebieg procesu jest wyraźnie uwarunkowany regionalnie. Najszybciej utożsamianie pierwotnie dwu odrębnych głosek - å pochylonego i $a$ jasnego - przebiega na Kresach Północno-Wschodnich (poddanych oddziaływaniom wschodniosłowiańskim, nieznającym samogłosek pochylonych), najwolniej zaś w Małopolsce, regionie najbardziej konserwatywnym językowo. I choć koniec XVII wieku nie przyniósł jeszcze w odniesieniu do polszczyzny ogólnej pełnej (ani nawet wstępnej) normalizacji, to jednak wyraźnie wyznaczył linię rozwojową. Obserwując kolejne dziesięciolecia i sytuację w poszczególnych regionach, stwierdzamy, że różnica artykulacyjna między å (pochylonym) i $a$ (jasnym) powoli, ale

12 Jedyne nieco wyraźniejsze odstępstwo od normy stanowi superlatywny przedrostek $n a$ - i naj-. Rozchwianie zapisów dotyczy obydwu postaci: zarówno przedrostka $n a-\mathrm{z}$ etymologiczną pochyloną samogłoską å, jak i jego postaci naj- (z etymologiczną jasną samogłoską $a$ ). I zapewne przyczyna częstych odstępstw od normy w zakresie pisowni obu wariantów tego przedrostka tkwi właśnie w różnej postaci występującej w nich głoski $a$ (raz pochylone å, drugim razem jasne $a$ ). W takiej sytuacji dochodzi do identyfikacji głosek, a tym samym do powstawania błędów z punktu widzenia ówczesnej normy tekstowej. Z czasem powtarzające się i nasilające nowe zwyczaje pisowniane na tyle się rozpowszechniają, że wchodzą na drogę normalizacji. 
konsekwentnie się zaciera ${ }^{13}$, a więc system dąży do utożsamienia zbyt mało zróżnicowanych artykulacyjnie i nieobciążonych fonologicznie głosek. Ostatecznie pełne wykrystalizowanie się nowej normy nastąpiło w XVIII wieku poprzez całkowitą eliminację głoski pochylonej å.

Istotnym problemem XVII-wiecznej polszczyzny literackiej jest zakres występowania samogłosek nosowych w różnych wyrazach, konkurowania postaci nazalizowanych i denazalizowanych. W ciągu XVII wieku w odniesieniu do wielu wyrazów obserwujemy kształtowanie się nowej normy językowej. Problem ten przedstawimy na wyrazistym przykładzie konkurującej ze sobą pary: miedzy - między. Pierwotna, etymologiczna postać miedzy jeszcze w XVI wieku stanowiła formę zdecydowanie dominującą. Przy około 84\% użyć14, obliczonych dla całego XVI stulecia, prezentowała stan niepełnej normalizacji. Nowa postać wyrazu, z wtórną nosowością perseweracyjną, w początkach XVII wieku ciągle jeszcze stanowiła wariant marginalny. Dopiero w drugiej ćwierci wieku rozpoczyna się jej ekspansja, ale mocno uwarunkowana regionalnie. Blisko $60 \%$ użyć, a więc poziom wstępnej normalizacji, notujemy tylko w Małopolsce, w pozostałych regionach ciągle jedynie od kilku do kilkunastu procent. Dalszy postęp w upowszechnianiu nowego wariantu między przynosi druga połowa XVII wieku. Małopolska osiąga już wówczas pełną normalizację (100\% użyć), Mazowsze przy blisko $65 \%$ użyć prezentuje poziom wstępnej normalizacji, jedynie Wielkopolska preferuje w dalszym ciągu wariant starszy, miedzy, który stanowi w regionie jeszcze ponad $65 \%$ użyć; nowe między tylko niespełna 35\%. Koniec XVII stulecia, jego ostatnia ćwierć, przynosi także w Wielkopolsce zwycięstwo nowszego wariantu między, który i w tym regionie osiąga stan niepełnej normalizacji, przekraczając wreszcie poziom 52\%. Na podobnym poziomie utrzymuje się nowa forma na Mazowszu, zaś w Małopolsce, od połowy wieku, nieodmiennie panuje stan pełnej normalizacji. Natomiast średnia ogólnopolska, obliczona na podstawie trzech regionów etnicznych (Małopolska, Wielkopolska, Mazowsze) pokazuje wzrastający systematycznie w kolejnych ćwierćwieczach poziom normalizacji, by pod koniec wieku znaleźć się już blisko poziomu niepełnej normalizacji (Pihan-Kijasowa 1994a: 118; 1999: 94-95) ${ }^{15}$. Zakończenie procesu normalizacyjnego nastąpi dopiero w następnym stuleciu.

W XVII wieku intensywnym zmianom podlega także fleksja. Przeobrażenia te dotyczą zarówno deklinacji, jak i koniugacji, prezentując zarówno procesy normalizacyjne o charakterze trwałym (jak np. unifikacja form celownika i miejscownika liczby mnogiej rzeczowników), jak i tendencje okresowe, w XVII wieku gwałtownie się nasilające, by później powrócić do stanu wcześniej już ustabilizowanego, jak np. zmiana przymiotnikowej końcówki w narzędniku liczby mnogiej -ymi $\|$-imi > -emi (typ dobrymi > dobremi).

13 Wniosek taki nasuwa analiza zapisów, ale, jak twierdzi Irena Bajerowa, niemożliwe się wydaje, by ówcześni drukarze i korektorzy potrafili poprawnie posługiwać się odnośnymi literami bez oparcia na aktualnym stanie w języku mówionym, gdyż pozycje w wyrazach i kategorie gramatyczne, w których występowało å (pochylone) i $a$ (jasne), były na tyle rozmaite i niewyraziste, że ich wyłącznie pamięciowe opanowanie wydaje się zbyt trudne (Bajerowa 1964: 45).

14 Obliczenia na podstawie Stownika polszczyzny XVI wieku (SPXVI 1981: XIII, 567-588).

15 Niższy średni odsetek nowych form między odnotowali autorzy Polszczyzny XVII wieku, ale, poza trzema regionami najbardziej normotwórczymi, w obliczeniach uwzględnili także Śląsk (z wyłączną formą miedzy) i Kresy, które, ze względu na regionalne tendencje fonetyczne, unikały samogłosek nosowych (Ostaszewska 2002: 51). 
Drugie z tych zjawisk, przemiany w zakresie końcówki narzędnikowej w liczbie mnogiej deklinacji przymiotnikowo-zaimkowej, stanowi swoiste pogranicze fonetyki i fleksji. Powodów przejścia końcówki -ymi $\|$-imi w -emi szuka się bowiem zarówno w czynnikach fonetycznych, jak i morfologicznych. Nie wnikając jednak w problem przyczyn zaistniałej zmiany, skupimy się jedynie na tempie jej przebiegu.

Narzędnikowa końcówka liczby mnogiej przymiotników i zaimków wszystkich trzech rodzajów odziedziczona została $\mathrm{z}$ prasłowiańszczyzny w postaci -ymi $\|$-imi. Stan taki zdecydowanie dominuje przez cały okres staropolski, choć już wtedy zdarza się i neologiczna końcówka -emi (Klemensiewicz, Lehr-Spławiński, Urbańczyk 1965: 336). Z czasem wzrasta frekwencja nowej końcówki. Jak twierdzi Zenon Klemensiewicz: „,...] w narzędniku 1. mn. wszystkich rodzajów dwie końcówki -emi i -imi $\|$-ymi występują obocznie z różnym nasileniem w różnych okresach [...]; -emi ma przewagę w XVI i XVII w. Próby normalizacji tej chwiejności przypadają na dobę nowopolską" (Klemensiewicz 1974: 301). Stan średni dla siedemnastowiecznej polszczyzny, liczony na podstawie tekstów wszystkich regionów ${ }^{16}$, potwierdza Klemensiewiczowską sugestię o przewadze końcówki -emi, szczególnie wyraźnej w drugiej połowie wieku (pierwsza ćwierć wieku $-59 \%$, druga ćwierć - 52\%, trzecia ćwierć - 75\%, ostatnia ćwierć - 62\%) (Ostaszewska 2002: 105). Można więc uznać, że pierwsza połowa wieku przedstawia stan wstępnej normalizacji, czyli odsetek użyć -emi przekroczył 50\%, tuż po połowie wieku dochodzi już do niepełnej normalizacji, czyli powyżej $75 \%$, by pod koniec wieku powrócić do stanu wstępnej normalizacji, czyli do poziomu poniżej 75\%. Stan w regionach jest jednak mocno zróżnicowany. Uwzględniając regiony etniczne mające podstawowe znaczenie dla kształtowania się ogólnej polszczyzny literackiej (Małopolska, Wielkopolska, Mazowsze) i dodając do tego prężne w XVII wieku Kresy Północno-Wschodnie, obserwujemy tempo przebiegu procesu normalizacyjnego mocno uwarunkowanego regionalnie. W początku XVII wieku największą frekwencję nowa końcówka -emi wykazywała w Małopolsce, osiągając tylko w tym regionie ponad 52\% użyć, czyli stan wstępnej normalizacji. Pozostałe regiony preferowały pierwotną końcówkę -ymi $\|$-imi. Sytuacja zmienia się około połowy wieku, kiedy to Kresy Północno-Wschodnie wyprzedziły pozostałe regiony we wprowadzaniu końcówki neologicznej (-emi), która przekroczyła 80\% użyć (niepełna normalizacja), pozostałe zaś przedstawiały stan wstępnej normalizacji. Początek drugiej połowy XVII wieku zachowuje poziomy normalizacji końcówki -emi z okresu poprzedniego na Kresach Północno-Wschodnich (niepełna normalizacja), w Małopolsce i na Mazowszu (w tych regionach nadal stan wstępnej normalizacji). Natomiast tendencja do upowszechniania tej końcówki wyraźnie wycofuje się z Wielkopolski, w której w trzecim ćwierćwieczu udział -emi spada zaledwie do niespełna 16\%. Koniec XVII wieku, poza Wielkopolską, osiąga już poziom pełnej normalizacji (Mazowsze i bardzo blisko tego stanu Kresy Północno-Wschodnie - 92\%) lub niepełnej normalizacji (Małopolska z blisko 80\% użyć -emi). Jedynie Wielkopolska stanowczo nie nadąża za tak szybkim upowszechnianiem tej końcówki, utrzymując ciągle w blisko 77\% pierwotną końcówkę -ymi $\|-i m i^{17}$ Ten stan nienadążania Wielkopolski za tempem przebiegu procesów normalizacyjnych szczególnie uwidocznił się w następnym

16 Małopolska, Wielkopolska, Kresy Północno-Wschodnie, Kresy Południowo-Wschodnie, Pomorze i Prusy, Śląsk (Ostaszewska 2002: 22).

17 Szczegółowe dane procentowe za: Pihan-Kijasowa 1999: 115. 
stuleciu. Irena Bajerowa, monografistka polszczyzny literackiej tego okresu, o Wielkopolsce pisze wręcz, że jest to: „Dzielnica najmniej ożywiona pod względem wydawniczym, o języku najbardziej archaicznym; w zakresie wielu cech zmieniających się w XVIII w. widzimy, że ogólny procent innowacji jest tu niższy niż w pozostałych regionach [...] Jest to więc język bardzo - można powiedzieć - «kulturalny», staranny, ostrożny, ale zacofany, opóźniony w rozwoju, martwy” (Bajerowa 1964: 218). Omawiany problem językowy (rywalizacja końcówek -ymi || -imi i -emi) sugeruje, że owo „opóźnienie w rozwoju” zaczęło się uwidaczniać już przed XVIII wiekiem.

Zjawiskiem wartym przypomnienia, a jednocześnie wyraziście pokazującym przebieg procesów normalizacyjnych, jest demorfologizacja rodzaju gramatycznego rzeczowników, obejmująca celownik, narzędnik i miejscownik liczby mnogiej. Na pierwszą połowę XVII wieku przypada zakończenie procesu normalizacji celownika i miejscownika (Rzepka 1985: 156 oraz tabela 33 i 34). Z rywalizujących w XVI i na początku XVII wieku końcówek zwyciężają: dla celownika -om i dla miejscownika -ach. Tak więc w zakresie tych form już początek XVII wieku problem normalizacji rozstrzygnął ostatecznie. Zmiany obejmujące narzędnik trwały natomiast znacznie dłużej, a w niektórych odmianach stylistycznych (teksty religijne, teksty o treści historycznej) stare formy narzędnika na $-y$ spotykane były nawet jeszcze w XIX wieku (Bajerowa 1992: 101-104). Jednakże to właśnie wiek XVII przesądził o kierunku rozwoju i zapoczątkował proces normalizacji narzędnika liczby mnogiej rzeczowników. Wiek XVI zakończył się zaledwie 25,5\% użyć zwycięskiej później końcówki -ami w rzeczownikach trzech rodzajów. Pierwsza ćwierć XVII wieku odsetek użyć tej końcówki podniosła już do 64,5\% użyć, czyli do poziomu wstępnej normalizacji. Był to więc skok bardzo gwałtowny. Druga połowa wieku, ze średnią użyć 77\%, pozostaje, co prawda, na poziomie wstępnej normalizacji, ale podwyższa odsetek użyć o kilkanaście procent (Rzepka 1985: 156 oraz tabela 33) ${ }^{18}$. Tendencja do utrzymania dobrego tempa przebiegu procesu normalizacyjnego została utrzymana, choć proces jeszcze w granicach XVII wieku nie zakończył się. W następnym stuleciu regresywna, ustępująca końcówka narzędnikowa $-y$ pojawia się już tylko w pojedynczych poświadczeniach (Bajerowa 1964: 86-87). Można na tej podstawie sądzić, że progresywna końcówka -ami osiągnęła w XVIII wieku poziom co najmniej bliski pełnej normalizacji. Wydaje się, że stan taki panował jeszcze przez znaczną część XIX wieku, by dopiero w końcowym jego okresie regresywne $-y$ wyeliminować $z$ użyć stylistycznie nienacechowanych, pozostawiając w kilku zaledwie formach spetryfikowanych, znanych też z polszczyzny dzisiejszej, jak: przed laty czy dawnymi czasy ${ }^{19}$. Przebieg procesu normalizacyjnego w zakresie narzędnika liczby mnogiej mocno był związany z rodzajem gramatycznym rzeczownika. Dla rzeczowników żeńskich końcówka -ami była pierwotna, natomiast spośród dwóch pozostałych szybciej i skuteczniej stabilizowała się w rzeczownikach męskich niż nijakich (Rzepka 1985: 63). Proces ten w rodzaju nijakim jest bardzo wyraźnie uwarunkowany leksykalnie

18 Podane liczby dotyczą tylko prozy, ale też były to teksty najbardziej stylistycznie neutralne. W poezji proces normalizacji przebiegał nieco wolniej i wzrósł z 36,5 \% na początku XVII wieku do 54\% w ostatnich jego dziesięcioleciach (Rzepka 1985: tabela 34).

19 Irena Bajerowa w odniesieniu do XVIII wieku już zauważa petryfikację kilku wyrazów z $-y$, pisząc: „Widać, jak od początku stulecia -y petryfikuje się w kilku formach, w których do dziś przetrwało” (Bajerowa 1964: 87). Podobne spostrzeżenie badaczka formułuje w odniesieniu do XIX wieku (Bajerowa 1992: 102). 
(Rzepka 1985: 63 i n.). Ponadto $\mathrm{w}$ obydwu rodzajach tempo procesu normalizacyjnego zależne jest też od typu tekstu (proza, poezja, odmiana urzędowa). Co do uwarunkowań regionalnych, powiedzieć można tylko ogólnie: -ami szerzyło się z północnych regionów Polski na południowe (Rzepka 1985: 104).

Wiek XVII jest także okresem interesującym i ważnym z punktu widzenia przebiegu procesów normalizacyjnych $\mathrm{w}$ zakresie fleksji werbalnej. Będąc centrum doby średniopolskiej, kontynuuje jeszcze procesy rozpoczęte $\mathrm{w}$ wieku XVI i jest czasem pojawiania się i nasilania nowych tendencji. Dzięki temu przez całe XVII stulecie obserwować można w zakresie fleksji werbalnej bogatą wariantywność. W czasie teraźniejszym rywalizują ze sobą końcówki pierwszej osoby liczby mnogiej typu: będziem \|| będziemy, a także, w zakresie koniugacji -ę, -isz (-ysz), typu: widzimy II widziemy. W czasie przeszłym pojawiają się resztki wariantywności typu: byłem \| byłech, bylismy \| bylichmy. Dodatkowo enklityki werbalne mogą być ruchome bądź unieruchomione przy imiesłowie, czyli może wystąpić zarówno forma któryś byt, jak i który byteś. W czasie zaprzeszłym spotyka się różne usytuowanie operatora byt: przed czasownikiem (na przykład byt zrobit), albo po czasowniku (zrobił byt). W czasie przyszłym złożonym wariantywność dotyczy zarówno szyku, jak i składu komponentów. Czasowniki w trybie rozkazującym mogą mieć aż trzy odmienne końcówki (-i, poszerzoną o jotę, czyli -ij, bądź zerową). Tryb przypuszczający charakteryzuje się zarówno wariantywnością końcówek członu by, jak i jego usytuowania. Wariantywność nie ominęła także imiesłowów. Oczywiście taka różnorodność w zakresie fleksji werbalnej każe postawić pytanie o kształt siedemnastowiecznej normy.

Niestety, w przeciwieństwie do fleksji imiennej, która, choć ciągle jeszcze niedostatecznie, zwłaszcza jeśli chodzi o regionalnie zróżnicowane tempo przebiegu procesów normalizacyjnych, jednak już w znacznym stopniu została opracowana, normalizacja fleksji werbalnej XVII stulecia w wielu problemach szczegółowych ciągle jest albo całkiem nierozpoznana, albo są to zaledwie wstępy do badań. Nie dysponujemy zwłaszcza informacjami o stanie normy języka literackiego w poszczególnych regionach. Jest to więc obszar do zagospodarowania. Nieco tylko lepiej przedstawia się sytuacja badań nad polszczyzną ogólną tego okresu. Co prawda problem normalizacji fleksji werbalnej został poruszony w pracach omawiających cały system języka polskiego XVII wieku, a także w kilku o charakterze bardziej szczegółowym, na ogół jednak nieco wnikliwiej omawiają one tylko wybrane procesy, o innych zaledwie wspominając. Sprawę dodatkowo utrudnia użycie przez badaczy różnych metod, przez co nie da się uzyskać jednego spójnego obrazu. Jednakże zamieszczone $\mathrm{w}$ tych pracach dane liczbowe ukazują pewien zarys normalizacji fleksji werbalnej w XVII wieku.

Obserwując procentowy udział poszczególnych wariantów w drukach z XVII stulecia, można zauważyć, że w obrębie koniugacji większość procesów normalizacyjnych bądź już się skończyło, bądź jeszcze nie zaczęło, tak więc trzon fleksji werbalnej w omawianym okresie był w dużym stopniu stabilny.

Według przywoływanych już wcześniej progów normalizacyjnych (do 50\% brak normy; od $51 \%$ do $74 \%$ wstępna normalizacja; od $75 \%$ do $94 \%$ niepełna normalizacja; od 95\% pełna normalizacja) w XVII stuleciu, w polszczyźnie ogólnej, uzyskaną wcześniej pełną normalizację utrzymywały tradycyjne końcówki czasu przeszłego: -(e)m (typ byłem) dla pierwszej osoby liczby pojedynczej, -(e)smy (typ bylismy), które występowało także z miękkim ś: -(e)śmy, dla pierwszej osoby liczby mnogiej. Pojawiające się od końca 
$\mathrm{XV}$ wieku formy przejęte $\mathrm{z}$ trybu przypuszczającego $-(e) c h,-(e) c h m y$ (typ byłech, bylichmy) już w drugiej połowie XVI stulecia zaczęły się z języka literackiego wycofywać. Ostatecznie wyszły z użycia w języku literackim w pierwszej połowie XVII wieku ${ }^{20}$. Przy czym szybciej wycofały się z czasowników liczby pojedynczej, dłużej utrzymywały się w liczbie mnogiej (Ostaszewska 2002: 166-167). Jako powód regresu tych wariantów większość badaczy przyjmuje przeniesienie stolicy, a zatem również życia umysłowego, z Krakowa do Warszawy, czyli na obszar mazowiecki, któremu końcówki - $(e)$ ch i - $(e)$ chmy nie były znane (Klemensiewicz 1974: 303-304; Klemensiewicz, Lehr-Spławiński, Urbańczyk 1965: 372; Długosz-Kurczabowa, Dubisz 2000: 308). A więc w tym przypadku można wskazać Mazowsze jako ten region, który wpłynął na likwidację wariantywności i ustalenie normy praktycznej w zakresie pierwszej osoby czasu przeszłego w liczbie pojedynczej i mnogiej.

Od początku XVII wieku na poziomie pełnej normalizacji utrzymują się również w czasie przeszłym formy syntetyczne (z enklityką werbalną unieruchomioną za imiesłowem, typu który byłeś). Natomiast wariantywne konstrukcje analityczne (z ruchomą enklityką werbalną, typu któryś byt), chociaż jeszcze pod koniec XVI wieku, według obliczeń Mirosławy Siuciak, miały przewagę, w XVII występują sporadycznie (od kilku do kilkunastu procent, nie wchodziły zatem nawet w granice wstępnej normalizacji, która rozpoczyna się od 50\%) (Ostaszewska 2002: 169-170). Jednakże według Aliny Kowalskiej sytuacja obu wariantów wygląda nieco inaczej - przez całe stulecie to formy analityczne wchodzą w zakres normy, uzyskując w pierwszej połowie XVII wieku 67\%, w 2 połowie 55\%. Widać zatem, że utrzymują się na poziomie między 51 a 74\%, to znaczy wstępnej normalizacji, choć ich udział rzeczywiście spada w drugiej połowie XVII wieku do nieomal samej granicy wstępnej normalizacji i braku normy (Kowalska 1976: 42-45, 55-59 i 63). Tak zasadnicza różnica w uzyskanym wyniku może być skutkiem nieprzystawalności przyjętych metod, którymi posługują się badaczki, a także doboru materiału. Problem więc należy podjąć raz jeszcze, by, na precyzyjnie dobranym materiale, z wykorzystaniem nowoczesnych metod badawczych, przekonywająco rozstrzygnąć.

Unieruchomienie enklityki werbalnej przy imiesłowie dokonało się w dobie nowopolskiej (Ostaszewska 2002: 169-170; Kowalska 1976: 42-45, 55-59), jednakże przykłady użycia szyku analitycznego spotykamy sporadycznie i dziś. Przyczyna dążenia języka do syntetyzacji członów tkwi, według Ewy Zawiślakowej, we fleksyjności języka polskiego. Fleksyjny charakter polszczyzny wymagał przesunięcia pozbawionej znaczenia leksykalnego końcówki osobowej na pozycję po temacie, w celu stworzenia z nim jednej całości. Dowodem całościowego traktowania tych form jest, zdaniem badaczki, stopniowe ustalanie się akcentu paroksytonicznego w syntetycznych formach liczby mnogiej (robil|ście, pracowal|iście) (Zawiślakowa 1974: 201).

Także w przypadku imiesłowu przymiotnikowego biernego przez całe XVII stulecie trwa ustanowiona już wcześniej norma. Wprawdzie w literaturze XVII-wiecznej spotyka się jeszcze w mianowniku liczby pojedynczej niezłożoną odmianę imiesłowu przymiotnikowego biernego - $n$, - $a$, -o (typu poznan, dan) (Klemensiewicz, Lehr-Spławiński, Urbańczyk 1965: 386), ale dominująca jest odmiana złożona o końcówkach -y, - $a$, -e (poznany,

20 Bogdan Walczak mówi o końcu XVI wieku, tymczasem Stanisław Urbańczyk, Zenon Klemensiewicz i Alina Kowalska o połowie XVII (Walczak 1999: 145; Klemensiewicz 1974: 303-304; Kowalska 1976: 25-27). 
dany). Władysława Książek-Bryłowa zauważa, że formy deklinacji niezłożonej pojawiają się w takich utworach, jak Kazania $i$ homilie na niedziele doroczne... S. Młodziankowskiego, Rozmyślania codzienne S. Solskiego. Nie ma ich natomiast w utworach Samuela Twardowskiego ${ }^{21}$, Wacława Potockiego czy Zbigniewa Morsztyna. Ignacy Krasicki nie posługuje się formami prostymi w Monachomachii ani Satyrach, pojawiają się za to sporadycznie w Bajkach. Badaczka dochodzi na tej podstawie do wniosku, że do XVIII wieku odmiana prosta imiesłowów utrzymywała się w tekstach religijnych (Książek-Bryłowa 1992: 165-166).

Wiek XVII kontynuował także dawną wariantywność zakończeń imiesłowu przysłówkowego uprzedniego, który dla czasowników z tematem bezokolicznikowym zakończonym na samogłoskę i niektórych spółgłoskowych przyjmował morfem -wszy, dla pozostałych -szy (Łoś 1922: 277). Ale już w połowie XVI wieku powstał, ze skrzyżowania imiesłowu na -ł z imiesłowem na -szy, nowotwór z zakończeniem -łszy. Zdaniem Ireny Bajerowej dodanie cząstki -ł- pozwoliło związać te formy z czasem przeszłym (Bajerowa 1964: 124; zob. też Bajerowa 1999: 390). Innowacja szerzyła się w czasownikach zakończonych na spółgłoskę. W zakresie wariantywności morfemów -szy i -łszy przez całe XVII stulecie pełną normalizację utrzymywał tradycyjny morfem -szy. Innowacyjne -łszy pojawia się zaledwie kilkakrotnie w 4 z 92 przebadanych przez autorów Polszczyzny XVII wieku drukach (Ostaszewska 2002: 178).

Stabilna w XVII stuleciu jest także sytuacja imiesłowu przymiotnikowego biernego czasowników z przyrostkiem -nq- (typ zamknać). Pełną normalizację utrzymuje tu pierwotne dla tej grupy zakończenie -ony. Jednakże już od początku XVII wieku pojawia się także morfem -ęty, pod wpływem form typu zapięty, zaczęty, wycięty (Ostaszewska 2002: 179). Nowe formy są jednak rzadkie. Mirosława Siuciak dla XVII wieku odnajduje dwa zaledwie przykłady użycia -ęty w wyrazie zamknięty (Ostaszewska 2002: 179). Na szerszą skalę formy te wprowadza dopiero XIX stulecie (Bajerowa 1964: 92).

W przedziale pełnej normalizacji trwa przez cały XVII wiek także prewerbalny szyk członu by $w$ trybie przypuszczającym. Wpływ na to miały, według Aliny Kowalskiej, właściwości stylu renesansowego: hipotaktyczność, rozbudowany system zapowiedników i odpowiedników zespolenia oraz finalny szyk orzeczenia. Wskaźniki nawiązania i zespolenia przyciągały enklityki na pozycję Wackernagla, co dodatkowo wspierało końcowe usytuowanie czasownika, ponieważ w polszczyźnie nie umieszcza się z reguły enklityk w wygłosie absolutnym (Kowalska 1976: 95-96). Syntetyzacja z imiesłowem następowała dużo rzadziej i takie formy przez wiek XVII nie wchodziły w granicę normy. W połowie XVII wieku widać jedynie ich nieznaczny wzrost z 4 do $8 \%$ w całości materiału zabranego przez A. Kowalską, z 5 do $10 \%$ w zdaniach nie determinujących miejsca enklityki werbalnej, co umotywowane jest częstszym niż we wcześniejszych stuleciach sytuowaniem orzeczenia na początku zdania. Jako drugi czynnik ich wzrostu można uznać rozpowszechniający się pod koniec doby średniopolskiej zwyczaj łączenia partykuły by ze słowem posiłkowym być, a także półposiłkowymi mieć, móc, musieć. Takie położenie by likwidowało wieloczłonowość orzeczenia, co dodatkowo działało na korzyść tego wariantu. Szyk

21 Iwo Szlesiński, badając język Samuela Twardowskiego, odnajduje sporadyczne użycia form imiesłowowych odmienianych według deklinacji rzeczownikowej. Wielkopolanin tworzył je w celach stylistycznych od form odmiany złożonej (Szlesiński 1968: 391). 
syntetyczny z członem by unieruchomionym za imiesłowem zaczął dominować dopiero w XX stuleciu (Książek-Bryłowa 1992: 169).

Drugą dużą grupę we fleksji werbalnej stanowią te procesy, w których przez większość stulecia warianty znajdowały się na progu niepełnej i pełnej normalizacji, ostatecznie osiągając jeszcze w XVII wieku poziom pełnej normalizacji.

Taka sytuacja panowała w pierwszej osobie liczby mnogiej czasu teraźniejszego. Wariant -my (typ będziemy), który pojawił się obok tradycyjnej -m (typ będziem) już w dobie przedpiśmiennej (zob. Wojtyła 1971; Śmiech 1967: 158-160) pod wpływem zaimka osobowego $m y^{22}$, przez wiek XVII utrzymywał się na granicy niepełnej (przedział od 75 do 94\%) i pełnej (powyżej 94\%) normalizacji. Obejmował, według ustaleń autorów Polszczyzny XVII wieku, w pierwszym ćwierćwieczu 88\%, w drugim 93\%, a w trzecim ćwierćwieczu 92\%. Jednakże jeszcze w omawianym stuleciu przekroczył na stałe próg pełnej normalizacji, uzyskując 95\% użyć. Rywalizująca z nią historyczna krótka końcówka - $m$ pojawia się w drukach przez cały wiek XVII, ale jej udział waha się, w zależności od regionu i klasy stylistycznej, od $16 \%$ do zaledwie 5\%, jest więc znacznie poniżej granicy normy. Dopiero wieki następne usuną jej resztki (Ostaszewska 2002: 162).

Nieco inny wynik dla końca XVII wieku uzyskała Irena Bajerowa. Mianowicie w ostatnim ćwierćwieczu tego stulecia zarejestrowała 30 przykładów form typu będziem (co stanowi aż 30\%), na 84 przykłady typu będziemy (70\%). Według tych danych innowacyjna końcówka -my nie wchodzi zatem jeszcze nawet $\mathrm{w}$ granice niepełnej normalizacji. Zaznaczyć jednak trzeba, że Irena Bajerowa opierała swoje wyliczenia zaledwie na 9 źródłach (dla ostatniego ćwierćwiecza XVII wieku), przy czym krótka końcówka - $m$ pojawiła się tylko w 4, natomiast autorzy Polszczyzny tylko dla lat 1691-1700 przebadali przeszło 20 tekstów, co dało znacznie większą podstawę materiałową obliczeń. Za koniec procesu zastępowania odziedziczonej końcówki - $m$ przez innowacyjną - $m y$ Irena Bajerowa przyjmuje wiek XVIII (Bajerowa 1964: 121), natomiast Witold Śmiech uznaje, że choć końcówka -my upowszechniła się znacznie wcześniej, to jednak jej resztki usunięte zostały dopiero w połowie XIX wieku (Śmiech 1967: 159), a Maria Wojtyła, uwzględniając piśmiennictwo kresowe, twierdzi, że dopiero u jego schyłku (Wojtyła 1971: 133).

Na poziomie niepełnej normalizacji trwa także przez niemal cały wiek XVII (przez trzy pierwsze ćwierćwiecza) innowacyjna forma wykładnika trybu przypuszczającego w pierwszej osobie liczby mnogiej bysmy (|| byśmy), konkurująca z tradycyjnymi, pochodzenia aorystycznego postaciami bychmy. Pojawiła się ona, podobnie jak pierwsza osoba liczby pojedynczej bym, w XV wieku na skutek upodobnienia do czasowników czasu przeszłego: byłem, bylismy. Już od początku wieku XVII znajdowała się w granicach niepełnej normalizacji (78\%), uzyskując do trzeciej ćwierci 85-86\%. Następnie w ostatnim ćwierćwieczu osiągnęła poziom pełnej normalizacji, obejmując 100\% form. Podobnie wyglądała sytuacja w pierwszej osobie liczby pojedynczej. Wprawdzie w początku omawianego stulecia bym jest na poziomie dopiero wstępnej normalizacji (pojawia się w 65\% wszystkich poświad-

22 Wpływ na to miała także potrzeba rozróżnienia pierwszej osoby liczby pojedynczej i mnogiej i, dodatkowo, proces kontrakcji zachodzący w III koniugacji prasłowiańskiej. Witold Śmiech zauważa jednak, że „z punktu widzenia funkcjonalnego końcówka -my była konieczna tylko u czasowników koniugacji III oraz V”, tymczasem pojawiała się niemal od początku również w I, II i IV i to w okresie, kiedy procesy ściągnięć nie były jeszcze zakończone (Śmiech 1967: 158-160). 
czeń dla pierwszej osoby liczby pojedynczej), ale już w drugim ćwierćwieczu osiąga próg niepełnej (występując w 85\%), a w drugiej połowie XVII wieku pełnej normalizacji (w 97\% k - 98,5\%) (Ostaszewska 2002: 167). Szczegółowsze obserwacje przebiegu procesu $\mathrm{w}$ regionach sugerują, że formy bym, bysmy||byśmy najszybciej osiągnęły poziom normalizacji w Wielkopolsce, natomiast bychmy utrzymuje się najdłużej na Kresach Wschodnich i w Małopolsce. Analogiczny przebieg procesu zauważamy też w odniesieniu do liczby pojedynczej (Ostaszewska 2002: 167-168).

W przypadku trybu rozkazującego widoczne jest zachwianie ustabilizowanej wcześniej normy. Wariant trybu rozkazującego z historyczną końcówką - $i$ utrzymywał się wśród czasowników o rdzeniu zbudowanym z grupy spółgłoskowej (typu tni, klni) na poziomie niepełnej normalizacji przez większość XVII stulecia, jego udział stale jednak się zmniejszał. W pierwszym ćwierćwieczu wariant ten obejmował aż 91\% wszystkich użyć, w drugim już $82 \%$, w trzecim 77\%, a w ostatnim ćwierćwieczu 65\%. Mimo ciągle wysokiego jeszcze udziału w tekstach, był to jednak wariant regresywny. Spadek liczebności form tradycyjnych następował na skutek tendencji języka do upraszczania systemu. Ich miejsce zajmowały czasowniki z końcówką zerową bądź poszerzoną o jotę (pod wpływem form typu: bij, $m y j$, w których -j należało do tematu) (Książek-Bryłowa 1992: 162-163). Pojawiały się zatem w XVII wieku wariantywnie wszystkie trzy możliwości: $-i,-i j,-\varnothing$ (Książek-Bryłowa 1992: 162-163). Przy czym, mimo ciągłego wzrostu form z -ij i -ø, w omawianym stuleciu nie weszły one jeszcze w granice normy, a tradycyjna końcówka - $i$ zanikła ostatecznie dopiero w dobie nowopolskiej (Ostaszewska 2002: 165).

Do ostatniej, niezbyt licznej grupy należą te procesy, w których w XVII wieku normalizacja jest dopiero na wstępnym etapie. Warianty będą się więc wahały na granicy braku normy i wstępnej normalizacji.

Taka sytuacja pojawia się w czasie teraźniejszym koniugacji -ę, -isz (-ysz). Od XIV/XV wieku obok czasowników typu widzimy, z historyczną dla tej koniugacji końcówką -im(y) pojawia się typ widziemy, z innowacyjną końcówką -em(y), która powstała na skutek czynników fonetyczno-morfologicznych. Do końca XVI wieku dominujący był historycznie właściwy typ widzimy. Dopiero wiek XVII stanowi dla tych wariantów czas przełomowy. W pierwszej połowie omawianego stulecia, jak dowodzą badania autorów Polszczyzny XVII wieku, obie końcówki balansowały na granicy wstępnej normalizacji i braku normy, obejmując od 49 do 51\% przykładów. W drugiej połowie XVII wieku powoli zwyciężał typ widziemy, obejmując w trzecim ćwierćwieczu 57\% wszystkich użyć, a w ostatnim już 69\%, co spowodowało zepchnięcie konkurencyjnego typu widzimy do braku normy.

Badacze zauważają, że przekształceniom ulegały przede wszystkim dłuższe zakończenia -imy (typ widzimy), o wiele zaś rzadziej formy z krótką końcówką -im (typ widzim). Rolę mógł tu odgrywać akcent. W przypadku widzimy akcent pada na różniącą się od pozostałych koniugacji samogłoskę, uwypuklając ją. W krótkim widzim nieakcentowana samogłoska nie jest tak rażąca (Śmiech 1967: 164). Z kolei Irena Bajerowa pewną niechęć do rozszerzenia krótszej końcówki -im w -em tłumaczy podobieństwem artykulacyjnym -em do -e występującego w pierwszej osobie czasu teraźniejszego oraz do -em w typie wiem, rozumiem (Bajerowa 1964: 121).

Wariantywność widziem(y) \| widzim(y) zanika ostatecznie w języku literackim w XIX wieku. Jej koniec jest prawdopodobnie skutkiem dążenia języka do wyrównywania paradygmatu, albowiem końcówka -em, -emy nie pasowała do pozostałych form koniugacji -e, 
-isz (-ysz), które we wszystkich osobach czasu teraźniejszego posiadały $i$. W wielu wypadkach stanowiło ono także część tematu. Na zanik wariantywnej końcówki niebagatelny wpływ miała również postawa Onufrego Kopczyńskiego, opowiadającego się w swej gramatyce za tradycyjną formą typu widzimy (Bajerowa 1964: 177-178; Śmiech 1867: 163-164; Ostaszewska 2002: 164).

Wahanie na granicy braku normy i wstępnej normalizacji widoczne jest również w czasie przyszłym złożonym. Od początku rozwoju polszczyzny bądź, według innych badaczy, od końca doby staropolskiej czas przyszły złożony wykazywał wariantywną budowę: do osobowej formy wyrazu być w czasie przyszłym dołączano bezokolicznik lub imiesłów na -ł (typ widział) ${ }^{23}$. Przy czym różny mógł być również szyk tych elementów: z prepozycją słowa posiłkowego być (typ będzie widzieć i będzie widziat) lub postpozycją (typ widzieć będzie i widział będzie) (Książek-Bryłowa 1992: 169). Typ imiesłowowy z członem posiłkowym w postpozycji zdarzał się niezwykle rzadko, częstszy był typ będzie widział, ale przeważały konstrukcje z bezokolicznikiem. Od XVI wieku zaczynają się rozprzestrzeniać formy imiesłowowe, powoli ograniczając użycie bezokolicznikowych. W wieku XVII, zdaniem Alicji Zagrodnikowej, przewaga wariantu z imiesłowem stale rośnie, przy czym zależna jest od stylu, liczby, rodzaju gramatycznego, a w liczbie mnogiej także charakteru czasownika. Tymczasem, według obliczeń Mirosławy Siuciak, konstrukcje z imiesłowem typu będzie widziat w początku XVII stulecia znajdują się w granicach wstępnej normalizacji, obejmując 57\% wszystkich użyć, a w drugiej połowie XVII wieku spadają poniżej granicy normy, obejmując już tylko 47 - 45\%. Natomiast wstępną normalizację uzyskują konstrukcje z bezokolicznikiem typu widzieć będzie pojawiające się w $51-52 \%$ przykładów. Użycie form bezokolicznikowych z członem być usytuowanym przed czasownikiem (typ będzie widzieć) ograniczało się przez całe stulecie do zaledwie kilku procent (Ostaszewska 2002: 176).

Inaczej sytuacja wyglądała w liczbie mnogiej, gdzie przeważały konstrukcje z bezokolicznikiem typu widzieć będziemy, oscylując w granicach wstępnej i, w drugiej połowie XVII wieku, niepełnej normalizacji. Rywalizowały przez całe stulecie głównie z konstrukcjami z bezokolicznikiem typu będziemy widzieć, których udział jednak nie przekroczył progu pełnej normalizacji i stale spadał (Ostaszewska 2002: 176).

Silne ścieranie się wariantów widoczne jest także w czasie zaprzeszłym, w którym walczyły ze sobą formy typu byt zrobit i zrobił byt. W dobie staropolskiej w czasie zaprzeszłym obowiązywał szyk byt + czasownik w czasie przeszłym, z przewagą ustawienia kontaktowego. Od połowy XVI wieku, ze względu na renesansową tendencję do oddalania składników form analitycznych i przesuwania podstawowego członu werbalnego na koniec wypowiedzenia, przyjęło się ramowe rozmieszczenie elementów czasu zaprzeszłego ${ }^{24}$. W XVII wieku sytuacja, według obliczeń autorów Polszczyzny XVII wieku, przedstawia się następująco: w pierwszym ćwierćwieczu typ byt zrobit obejmuje $71 \%$, wszystkich użyć,

23 Takie dane pojawiają się w gramatykach historycznych (Klemensiewicz, Lehr-Spławiński, Urbańczyk 1965: 374; Rospond 1971: 179; Długosz-Kurczabowa, Dubisz 2000: 310), natomiast Władysława Książek-Bryłowa pisze, że formy imiesłowowe pojawiły się w XV wieku (Książek-Bryłowa 1992: 169).

24 Konstrukcja z prewerbalnym był zezwala na takie zmiany, w przeciwieństwie do szyku z postpozycją. W dobie staropolskiej układ kontaktowy obejmował 72\% przykładów form czasu zaprzeszłego, ale od połowy XVI wieku obserwować można ich spadek do średnio 55\% w dobie średniopolskiej (Kowalska 1976: 69-70). 
sytuuje się zatem w przedziale wstępnej normalizacji, natomiast typ zrobit byt tylko 29\%, W drugim ćwierćwieczu typ byt zrobit obejmuje 53\%, typ zrobit byt już 47\%. W trzecim typ byt zrobił pojawił się już tylko w 35\%, tymczasem typ zrobił byt w 65\%. W ostatnim dziesięcioleciu sytuacja zasadniczo się nie zmieniła - typ byt zrobił uzyskuje $43 \%$, a zrobit byt $57 \%$. Widać zatem, że w XVII wieku element byt z prepozycji zaczął przechodzić do postpozycji, która uniemożliwiała ramową konstrukcję członów czasu zaprzeszłego w zdaniu i pod koniec stulecia osiągnął próg wstępnej normalizacji, spychając szyk byt + czasownik do braku normy, nie osiągając jednak przez cały wiek XVII progu nawet niepełnej normalizacji (Ostaszewska 2002: 173).

Powyższe ustalenia nie wyczerpują problemu normalizacji fleksji werbalnej w XVII wieku. Język literacki stanowił bowiem w tym okresie twór jeszcze niejednolity, dość mocno zróżnicowany regionalnie.

Irena Bajerowa w pracy o Kształtowaniu się systemu polskiego języka literackiego w XVIII wieku pisze, że w okresie zwiększającej się żywotności procesu różnice między poszczególnymi odmiankami powiększają się, następnie, gdy proces przybiera na sile i obejmuje swym zasięgiem coraz większe terytorium, różnice te zaczynają się zmniejszać. Wreszcie różnice regionalne zanikają, gdy zwyciężone zostają najbardziej oporne ich centra, i proces dobiega końca (Bajerowa 1964: 218).

Tak więc w większej części fleksji werbalnej, która charakteryzowała się dużym już znormalizowaniem, zróżnicowanie regionalne nie będzie prawdopodobnie zbyt wyraźne. Hipotezę taką można postawić jedynie na podstawie ogólnego oglądu siedemnastowiecznych źródeł drukowanych, bowiem odpowiednimi szczegółowymi wyliczeniami i opracowaniami ciągle jeszcze w odniesieniu do koniugacji nie dysponujemy. Natomiast zróżnicowanie regionalne, jak można sądzić, zaobserwujemy w tych procesach, w których warianty ścierają się na granicy braku normy i wstępnej normalizacji. Taka sytuacja występuje na przykład w pierwszej osobie liczby mnogiej czasu teraźniejszego koniugacji -ę, -isz $(-y s z)$.

W pierwszej połowie XVII wieku, jak dowodzą badania autorów Polszczyzny XVII wieku, końcówki pierwszej osoby liczby mnogiej -imy (-ymy) i innowacyjna -emy balansowały na granicy wstępnej normalizacji i braku normy. W pierwszym ćwierćwieczu końcówka historyczna -imy (-ymy) obejmowała 51\% wszystkich użyć, -emy 49\%. W drugim ćwierćwieczu -imy (-ymy) obejmowała 49\% wszystkich użyć, innowacyjna -emy 51\%. Można się więc spodziewać, że wyliczony przez badaczy stan średni dla ogólnej polszczyzny XVII wieku nie musi być zgodny ze stanem w odmianach regionalnych. Jednak, jak wyżej wspominałyśmy, stan języka literackiego w poszczególnych regionach dla interesującego nas tu wieku XVII nie został jeszcze wystarczająco opracowany. By więc hipotezę o zróżnicowaniu regionalnym przebiegu procesów normalizacyjnych w zakresie koniugacji (na przykładzie oboczności -imy \| -emy) udowodnić, przeprowadzimy analizę na podstawie materiału wyekscerpowanego na potrzeby niniejszego studium z dwóch regionów - Wielkopolski i Małopolski.

Badaniami objęte zostały druki z pierwszej połowy XVII wieku, z lat 1611-1646. Wielkopolskie: Politica. O wolności Polski Pospolitey Kaspra Pepłowskiego, wydany w Poznaniu w 1611 roku, Kazanie na pogrzebie Jaśnie Wielmożney Paniey Jey Mości P. Anny z Czarnkowa Przyiemskiey Jerzego Godziszewskiego, wydany w Poznaniu w 1629 roku, Archelia, to iest nauka y informatia o strzelbie Jana Dekana wydany w Lesznie w 1643 
roku i Pociecha przednim uczczona mieyscem Stanisława Dydaka Melera wydany w Poznaniu w 1646 roku. Druki małopolskie: Prawy szlachcic, w kazaniu na pogrzebie ś. pamięci Jego Mości Pana Andrzeia ze Żmigroda Stadnickiego Andrzeja Radawickiego wydany w Krakowie w 1614 roku, tegoż: Prawy Oycowic, w kazaniu na pogrzebie sławney pamięci Iego Mci Pana Mikołaia ze Żmigroda Stadnickiego wydany w Krakowie w 1630 roku, Kometa to iest pogróżka z nieba Mateusza Bembusa wydany w Krakowie w 1619 roku. O doborze tekstów decydowało przede wszystkim miejsce wydania. Jednak dodatkowym kryterium było miejsce pochodzenia autora tekstu. Starano się zachować zasadę, by region, w którym tekst został wydany, był także regionem, z którego pochodził jego autor bądź też był z nim przez dłuższy czas związany, czyli „wżyty” w region. Badania zostały oparte na próbie 20 tys. słów w przypadku większych tekstów, mniejsze ekscerpowano w całości. Formy pierwszej osoby liczby mnogiej spotykane są w tekstach rzadko. Wiąże się to przede wszystkim z narracją, która prowadzona jest na ogół w 3 osobie. Ze względu na to, zgromadzony materiał nie jest zbyt wielki, ale z pewnością porównywalny, a nawet przewyższający liczbę form przywoływanych w pracach innych autorów.

Zebrany materiał pokazuje, iż w pierwszej połowie XVII wieku w Wielkopolsce niezwykle silna jest innowacyjna końcówka -emy. Obejmuje ona 41 czasowników, co stanowi przeszło 87\% wszystkich użyć. Natomiast wariantywna końcówka -imy (-ymy) nie przekracza przedziału do 50\%, określanego jako brak normy.

Zatem w okresie, gdy polszczyzna ogólna wykazywała w zakresie repartycji końcówki -emy brak normy bądź wstępną dopiero normalizację, w wielkopolskiej odmianie języka literackiego -emy przekroczyła już próg niepełnej normalizacji.

Tymczasem w Małopolsce -emy w pierwszej połowie XVII wieku nie wchodziło w granicę normy w ogóle, obejmując zaledwie 37\% czasowników, natomiast wstępną normalizację osiąga -imy (63\%).

Sprawa komplikuje się jeszcze bardziej, gdy zwraca się uwagę na pojedyncze źródło. Na przykład w Politice Kaspra Pepłowskiego z roku 1611 (druk wielkopolski) końcówka innowacyjna obejmuje ponad 93\% wszystkich form, a po dodaniu leksemów, które pojawiły się poza badaną próbą, końcówka ta zwiększy swój udział do ponad 94\%. Można tu więc mówić o pełnej już normalizacji. Tymczasem w pierwszym ćwierćwieczu siedemnastego stulecia -emy w polszczyźnie ogólnej obejmowało zaledwie 49\% (brak normy).

W małopolskim druku: Kometa to iest pogróżka z nieba Mateusza Bembusa z roku 1619 innowacyjna -emy obejmuje tylko 20\%, natomiast historyczna -imy aż $80 \%$, wchodząc w granice niepełnej normalizacji.

Są to druki, w których różnica między regionalnymi odmiany polszczyzny literackiej jest najbardziej widoczna. Jednak nawet w pozostałych tekstach, które nie wykazują tak dużej różnicy w stosunku do średniej ogólnopolskiej, odmienność regionów pozostaje ciągle wyraźna. W druku Jana Dekana (Wielkopolska) końcówka -emy stanowi przeszło 66\% użyć, znajduje się zatem na etapie wstępnej normalizacji, -imy 33\%. Natomiast w Prawym Oycowicu Andrzeja Radawickiego (druk małopolski) -emy obejmuje 43\%, co oznacza brak normy, a z kolei -imy przy 57\% osiąga etap wstępnej normalizacji.

Wydaje się, że przyczyną tak wyraźnej różnicy między drukami wielkopolskimi, preferującymi końcówkę -emy, a małopolskimi, z przewagą -imy, była większa w Wielkopolsce niż w innych regionach skłonność do obniżania artykulacji samogłosek wysokich przed 
spółgłoskami nosowymi ${ }^{25}$. Zjawisko to widoczne jest także w innych procesach, na przykład w zmianie typu siła $\geq$ sieła (Pihan-Kijasowa 1999: 108).

Przytoczony materiał egzemplifikacyjny z zakresu fonetyki, fleksji imiennej i fleksji werbalnej, choć pokazujący pojedyncze tylko fakty językowe, pozwala podtrzymać wyrażoną wcześniej tezę o sporej już normalizacji literackiej polszczyzny XVII wieku. Wiele zasad użycia języka wytworzyło się już wcześniej, w XVI wieku, a więc XVII wiek odziedziczył wykrystalizowane normy tekstowe. Ale też odziedziczył rozpoczęte wcześniej procesy normalizacyjne, doprowadzając je w omawianym okresie do wykształcenia norm trwałych bądź okresowych, inne zaś procesy dopiero w XVII wieku się zawiązywały, lata późniejsze doprowadzały do ostatecznych rozstrzygnięć. Przekonująco więc brzmi całościowa ocena XVII wieku zawarta w syntetycznym opracowaniu Polszczyzna XVII wieku. Stan i przeobrażenia. Autorzy bowiem konkludują: „Polszczyzna stanowi w XVII wieku dojrzały system - z wyraźnie wyodrębnioną odmianą ogólną, funkcjonującą zarówno na płaszczyźnie mówionej, jak i pisanej. Zdecydowała o tym zwłaszcza dbałość o poziom języka w pierwszej połowie tego stulecia. Następne półwiecza, kiedy sytuacja zewnętrzna staje się niekorzystna dla funkcjonowania języka polskiego, odziedziczyły więc ukształtowany już stan ogólnej polszczyzny literackiej, która wyraźnie odróżniała się od gwar. Stabilizacji owej nie były już w stanie naruszyć późniejsze klęski” (Ostaszewska 2002: 18).

Nie znaczy to jednak, że badania wieku XVII są już ukończone. Jak na wstępie sygnalizowałyśmy, nasza wiedza o polszczyźnie tego okresu jest ciągle daleka od kompletności. Znamy w zarysie procesy ogólne, przedstawiające uśredniony stan ówczesnej polszczyzny literackiej. Ale też mamy świadomość, jak rzeczywistość językowa od stanu uśrednionego odbiegała. Skoro jeszcze w odniesieniu do XVIII wieku Irena Bajerowa powiada, że: „Język literacki XVIII w. nie jest jeszcze jednolity. Łatwo odnajduje się w nim przeróżne cechy regionalne" (Bajerowa 1964: 201), tym bardziej można tezę taką przyjąć w odniesieniu do wieku poprzedniego. Ujawniły to chociażby wyżej przedstawione nieliczne przykłady zróżnicowania regionalnego w zakresie tempa przebiegu procesów normalizacyjnych. Nieliczne, bowiem w odniesieniu do wieku XVII problem ten czeka ciągle na opracowanie. Wydaje się, że jest to jedno z najpilniejszych zadań stojących przed historykami polszczyzny XVII wieku. Dopiero bowiem szczegółowe dane statystyczne, pokazujące udział konkretnych wariantów fonetycznych czy fleksyjnych w regionalnych odmianach języka, pozwolą nam wskazać, gdzie rozpoczynają się zmiany językowe, skąd szerzą się nowe normy językowe, które regiony są w tych procesach najbardziej innowacyjne, najszybciej przeprowadzają procesy normalizacyjne, które zaś pozostają w tyle, nie nadążając za nimi.

\section{Bibliografia}

Bajerowa I., 1964, Kształtowanie się systemu polskiego języka literackiego w XVIII wieku, Wrocław. Bajerowa I., 1978, O zaniku samogłosek pochylonych (pokłosie dyskusji), Katowice.

Bajerowa I., 1979, Normalizacja polskiej ortografii w XIX wieku, w: Opuscula Polono-Slavica, red. J. Safarewicz, Wrocław, s. 38-46.

25 Alicja Pihan-Kijasowa odnotowuje dla Wielkopolski w pierwszej połowie XVII wieku bardzo wyraźną, w porównaniu z pozostałymi regionami, przewagę końcówki -emy/-emi (Pihan-Kijasowa 1999: 112). 
Bajerowa I., 1980, Zmiany fleksji zaimków w XIX-wiecznej polszczyźnie ogólnej (normalizacja i przeksztatcenia normy), „Język Polski” LX, s. 105-114.

Bajerowa I., 1986, Polski język ogólny XIX wieku. Stan i ewolucja, t. I: Ortografia, fonologia z fonetyka, morfonologia, Katowice.

Bajerowa I., 1992, Polski język ogólny XIX wieku. Stan i ewolucja, t. II: Fleksja, Katowice.

Bajerowa I., 1999, [Rec.] Krystyna Dlugosz-Kurczabowa, Stanisław Dubisz, Gramatyka historyczna języka polskiego. Podręcznik dla studentów polonistyki. Wydawnictwa Uniwersytetu Warszawskiego 1998, s. 334, „Język Polski” 79, nr 5, s. 387-390.

Borecki M., 1974, Kształtowanie się normy językowej w drukach polskich XVI wieku (na przykładzie oboczności pirwszy \|| pierwszy), Wrocław.

Borek H., 1962, Język Adama Gdaciusza (przyczynek do historii polszczyzny ślaskiej), Wrocław.

Breza E., 1979, Uwagi o fonetyce i fleksji języka polskiego na Pomorzu w XVI-XVII w. na podstawie rękopiśmiennych ksiag sadowych kościerskich, „Studia z Filologii Polskiej i Słowiańskiej”, t. 18, s. 51-65.

Buttler D., Kurkowska H., Satkiewicz H., 1971, Kultura języka polskiego. Zagadnienia poprawności gramatycznej, Warszawa.

Cybulski M., 1992, Norma języka literackiego wobec normy rękopiśmiennych tekstów urzędowych z XVII wieku, w: Odmiany polszczyzny XVII wieku, red. H. Wiśniewska, C. Kosyl, Lublin, s. 17-27.

Długosz-Kurczabowa K., Dubisz S., 2000, Gramatyka historyczna języka polskiego, Warszawa.

Jefimow R., 1970, Z dziejów języka polskiego w Gdańsku. Stan wiedzy o polszczyźnie w XVII wieku, Gdańsk.

Kamińska M., 1953, Pisownia druków polskich XVII wieku, „Prace Polonistyczne” XI, s. 5-28.

Karpluk M., 1967, Język Jana Jurkowskiego (1580-1639), Wrocław.

Klemensiewicz Z., 1974, Historia języka polskiego, Warszawa (pierwsze wydanie: Historia języka polskiego, t. 2: Doba średniopolska, Warszawa 1965).

Klemensiewicz Z., Lehr-Spławiński T.,. Urbańczyk S, 1965, Gramatyka historyczna języka polskiego, Warszawa.

Korotaj W., 1970, Dynamika rozwoju piśmiennictwa polskiego od połowy XVI do końca XVII wieku, w: Wiek XVII - Kontrreformacja - Barok, red. J. Pelc, Warszawa, s. 275-298.

Kosyl C., 1978, Wtaściwości fonetyczne polszczyzny kresowej w pierwszej połowie XVII w. (na przykładzie języka mieszczan hrubieszowskich), „Studia z Filologii Polskiej i Słowiańskiej”, t. 17, s. $104-121$.

Kowalska A., 1973, Końcówka -ej w odmianie rzeczowników rodzaju żeńskiego $w$ języku polskim, „Prace Językoznawcze”, t. 2, red. I. Bajerowa, W. Lubaś, Katowice, s. 59-81.

Kowalska A., 1976, Ewolucja analitycznych form czasownikowych z imiestowem na $-t$ w języku polskim, Katowice.

Książek-Bryłowa W., 1986, Uwarunkowania społeczne normy językowej w XVI wieku, „Rozprawy Komisji Językowej Łódzkiego Towarzystwa Naukowego" 32, s. 139-146.

Książek-Bryłowa W., 1992, Warianty fleksyjne w historii języka polskiego, w: T. Skubalanka, W. Książek-Bryłowa Wariantywność fleksji polskiej, Wrocław, s. 117-190.

Lisowski T., 1999, Polszczyzna początku XVI wieku. Problemy wariantywności i normalizacji fonetyki i fleksji, Poznań.

Łoś J., 1922, Gramatyka polska, Lwów-Warszawa-Kraków.

Migdał J., 1999, O języku Andrzeja Glabera z Kobylina. Studium normalizacji polszczyzny wczesnorenesansowej, Poznań.

Motyl A., 2009, Wokół dyskusji o kondycji polskiego języka literackiego w XVII wieku, „Poznańskie Studia Polonistyczne. Seria Językoznawcza” XV (XXXV), s. 205-221.

Olesch R., 1992, O podręcznikach języka polskiego drukowanych na Śląsku w XVII wieku, w: Barok w polskiej kulturze, literaturze i języku, red. M. Stępień, S. Urbańczyk, Warszawa-Kraków, s. 131-139. 
Ostaszewska D. (red.), 2002, Polszczyzna XVII wieku. Stan i przeobrażenia, Katowice.

Pawłowska R., 1979, Fonetyka języka polskiego nauczanego w Gdańsku w XVII wieku, Gdańsk.

Pihan-Kijasowa A., 1994a, Mechanizmy ksztaltowania się norm języka literackiego polszczyzny pólnocnokresowej XVI i XVII wieku, w: Uwarunkowania i przyczyny zmian językowych. Zbiór studiów, red. E. Wrocławska, Warszawa, s. 113-119.

Pihan-Kijasowa A., 1994b, Zakresy występowania a - á w drukach pótnocnokresowych XVII wieku, w: Studia nad polszczyzna kresowa, t. VII, red. J. Rieger, Wrocław-Warszawa-Kraków, s. 179-187.

Pihan-Kijasowa A., 1999, Literacka polszczyzna kresów pótnocno-wschodnich XVII wieku. Fonety$k a$, Poznań.

Puzynina J., 1961, „Thesaurus” Grzegorza Knapiusza. Siedemnastowieczny warsztat pracy nad jezykiem polskim, Wrocław.

Pyrkosz A., 2010, Asymilacje pod względem dźwięczności w grupach spółgłoskowych w polszczyźnie XVI i pierwszej połowy XVII wieku (na podstawie druków krakowskich), „Poznańskie Studia Polonistyczne. Seria Językoznawcza” XVI (XXXVI), s. 227-239.

Rospond S., 1971, Gramatyka historyczna języka polskiego. Warszawa.

Rykiel B., 1963, O języku Wilczków - mieszczan lwowskich XVII w., „Poradnik Językowy”, z. 1, s. 32-39.

Rzepka W.R., 1968, Uwagi o genetivie-accusativie pluralis meskich form osobowych w XVII wieku, „Slavia Occidentalis” 27, s. 207-222.

Rzepka W.R., 1975, Dopetniacz $w$ funkcji biernika męskich form osobowych $w$ liczbie mnogiej w polszczyźnie XVII wieku, Wrocław.

Rzepka W.R., 1978, Męskoosobowy mianownik liczby mnogiej zaimków i przymiotników typu „naszy najlepszy || nasi najlepsi” w polszczyźnie XVII wieku, „Studia z Filologii Polskiej i Słowiańskiej”, t. 17, Warszawa, s. 187-195.

Rzepka W.R., 1985, Demorfologizacja rodzaju w liczbie mnogiej rzeczowników w polszczyźnie XVIXVII wieku, Poznań.

Rzepka W.R., 1986, Z dziejów form fleksyjnych rzeczowników w polszczyźnie XVI-XVII wieku: celownik liczby pojedynczej rodzaju męskiego, „Slavia Occidentalis” 43, s. 135-158.

Siekierska K., 1962, Liczebniki nieokreślone w języku polskim XVII w., „Poradnik Językowy”, z. 2/3, s. 49-61, 114-133.

Siekierska K., 1969, Wtórna nosowość antycypacyjna w języku polskim (na przykładzie niektórych pisarzy XVII wieku), „Prace Filologiczne” 19, Warszawa, s. 29-40.

Siekierska K., 1974, Język Wojciecha Stanisława Chrościńskiego. Studium mazowieckiej polszczyzny z przełomu XVII i XVIII wieku, Wrocław.

Skubalanka T., 1992, Warianty fleksyjne we współczesnej polszczyźnie, w: T. Skubalanka, W. Książek-Bryłowa, Wariantywność polskiej fleksji, Wrocław, s. 7-116.

SPXVI 1966-2012 - Stownik polszczyzny XVI wieku, red. M.R. Mayenowa, F. Pepłowski, K. Mrowcewicz, t. I-XXXVI, Wrocław-Warszawa-Kraków.

Stępień M., Urbańczyk S. (red.), 1992, Barok w polskiej kulturze, literaturze i języku, Warszawa-Kraków.

Stieber Z., 1947, Uwagi o języku Wacława Potockiego, „Prace Polonistyczne”, seria V, Łódź, s. 9-32.

Szlesiński I., 1968, Język Samuela Twardowskiego (fonetyka i fleksja), „Rozprawy Komisji Językowej Łódzkiego Towarzystwa Naukowego", t. 14, Łódź, s. 333-400.

Szlesiński I., 1970a, Język Samuela Twardowskiego (słowotwórstwo), „Rozprawy Komisji Językowej Łódzkiego Towarzystwa Naukowego", t. 15, s. 189-236.

Szlesiński I., 1970b, Język Samuela Twardowskiego (frazeologia i sktadnia), „Rozprawy Komisji Językowej Łódzkiego Towarzystwa Naukowego", t. 16, s. 87-120.

Szlesiński I., 1971, Język Samuela Twardowskiego (słownictwo), „Rozprawy Komisji Językowej Łódzkiego Towarzystwa Naukowego", t.17, s. 155-198. 
Śmiech W., 1967, Rozwój form czasu teraźniejszego czasownika w języku polskim, Łódź.

Topolska M.B., 1984, Czytelnik i książka w Wielkim Księstwie Litewskim w okresie Renesansu i Baroku, Wrocław.

Urbańczyk S., 1992, Sytuacja językowa w Polsce XVII wieku, w: Barok w polskiej kulturze, literaturze i języku. Materiaty z konferencji naukowej 25-29 sierpnia 1987 w Krakowie, red. M. Stępień i S. Urbańczyk, 237-249.

Walczak B., 1999, Zarys dziejów języka polskiego, Wrocław.

Wiśniewska H., 1992, Sytuacja języka polskiego w XVII wieku, w: Odmiany polszczyzny XVII wieku, red. H. Wiśniewska, C. Kosyl, Lublin, s. 7-16.

Wiśniewska H., Kosyl C. (red.), 1984, Polszczyzna regionalna $w$ okresie renesansu i baroku, Wrocław.

Wiśniewska H., Kosyl C. (red.), 1992, Odmiany polszczyzny XVII wieku, Lublin.

Wojtyła M., 1971, Oboczność końcówek 1 os. l. mn. czasu teraźniejszego czasownika -m/-my w historii języka polskiego, „Prace Językoznawcze. Zeszyty Naukowe UJ”, z. 35, s. 125-150.

Wróbel A., 1987, Chetmińskie księgi kamlarskie z XVII i XVIII w. Studium językowe, Toruń.

Zawiślakowa E., 1974, Końcówki ruchome czasu przeszłego, „Język Polski” 54, s. 195-202.

Zwoliński P., 1988, Gramatyki języka polskiego z XVII wieku jako źródło poznania ówczesnej polszczyzny, w: P. Zwoliński, Szkice i studia z historii slawistyki. Wyboru dokonał M. Basaj, Wrocław-Warszawa-Kraków-Gdańsk-Łódź, s. 31-66.

ALICJA PIHAN-KIJASOWA (UAM Poznań), AGNIESZKA MOTYL (UAM Poznań)

\title{
Major issues in normalization of the 17th century Polish language
}

\section{Summary}

\begin{abstract}
Research into the literary Polish language of the 17th century was undertaken relatively late. No significant relevant attempts had been made before the mid-20th century. The first detailed studies were made in the 1950s while the 1970s marked significantly advanced studies on the subject. The first monograph of the 17th century Polish language was published as late as in 2002. However, the monograph, presenting the entire grammar system together with the spelling rules and phonetics, does not conclude research into this period as it is rather general and fails to discuss many major issues related to the language's evolution, for example the regional conditionings of the course of the normalization processes. This is a shortage plaguing many works on the 17th century Polish language. Therefore, it is very difficult to reconstruct the emergence and geographic distribution of linguistic innovations, over time transferring into a language norm. As for the 17th century, we can only refer to the text norm (or a practical norm/usus). In the century in question, a codified (theoretical) norm had not yet been developed although the grammar instructions from that time include some guidelines on linguistic correctness. As printing had already been well developed, we have enough sources to reconstruct text norms and to show its evolution. By referring to studies and text overviews one may conclude that the 17 th century inherited from the 16th century a system largely normalized on various levels: the spelling, phonetics and morphology. On the other hand, it also either inherited or produced co-functional variants which only aspired to becoming a part of the norm. On the basis of selected issues from the realm of phonetics, declension and conjugation, the article shows examples of norms inherited from the previous century and, more importantly, processes of new linguistic norms emerging in the 17th century. These processes have been presented not only in reference to the averaged status in the general Polish language but also, whenever possible, their course is presented in the regional varieties of the language. By resorting to the methodology and terminology developed by Irena Bajerowa, the authors have touched upon the issue of the regionally diversified rate of the normalization processes. However, with reference to the 17 th century, we are not able to present many linguistic facts in this specific way. What we
\end{abstract}


need is detailed statistical research that shows the share of the specific variants in the regional variations of the Polish language, in several synchronic sectional views (vertical time segments). This research procedure will allow to show the source of new linguistic norms, the rate at which they disseminate and which regions are the most innovative ones.

Keywords: Polish language in the 17th century, language variants, linguistic awareness, text norm, normalization process. 